Callister, Graeme ORCID:

https://orcid.org/0000-0003-3651-3919 (2021) Britain's Not-soGrand Strategy: The Projected Expedition Against the Texel, 1796. Academia Letters.

Downloaded from: http://ray.yorksj.ac.uk/id/eprint/5565/

The version presented here may differ from the published version or version of record. If you intend to cite from the work you are advised to consult the publisher's version: https://www.academia.edu/52696691/Britains_Not_so_Grand_Strategy_The_Projected_Ex pedition_Against_the_Texel_1796

Research at York St John (RaY) is an institutional repository. It supports the principles of open access by making the research outputs of the University available in digital form. Copyright of the items stored in RaY reside with the authors and/or other copyright owners. Users may access full text items free of charge, and may download a copy for private study or non-commercial research. For further reuse terms, see licence terms governing individual outputs. Institutional Repository Policy Statement

\title{
RaY
}

Research at the University of York St John

For more information please contact RaY at ray@yorksj.ac.uk 


\title{
ACADEMIA $\mid$ Letters
}

\section{Britain's Not-so-Grand Strategy: The Projected Expedition Against the Texel, 1796}

\author{
Graeme Callister
}

The French conquest of the Netherlands in early 1795 left Britain in an invidious strategic position. Not only had the main British field army been badly beaten, but French dominance of the Low Countries left her vulnerable to invasion from across the North Sea. The purpose of this article is to outline one of the British government's responses to this strategic concern, in the shape of a proposed expedition in October 1796 to raid and destroy Dutch shipping in the Texel. This event - or non-event, as the case may be - has been largely overlooked in the histories of the period. The fullest treatment can be found in Earl Camperdown's 1898 biography of his great-grandfather, Admiral Adam Duncan, commander of the expedition's naval forces. ${ }^{1}$ Another classic work, John Fortescue's History of the British Army, offers a brief account of the planning, heavily skewed towards criticism of Secretary for War Henry Dundas. ${ }^{2}$ More recent analyses of British strategy and operations have given the Texel project little attention. It does not feature, for example, in Robert Sutcliffe's assessment of British expeditionary warfare in the 1790s, and it is alluded to only in passing by Roger Knight as one of 'a succession of non-events and failures'. 3

This lack of attention is understandable. The projected expedition was of relatively small scale, planned and dispatched without fanfare, and returned without having fired a shot in anger. It merited a brief mention in the daily newspapers in early November 1796 but made almost no ripple in the public consciousness. Even the official records of the event are patchy.

\footnotetext{
${ }^{1}$ Earl of Camperdown, Admiral Duncan (London: Longmans, Green \& Co., 1898), pp.79-90.

${ }^{2}$ J.W. Fortescue, History of British Army (20 vols, London: Macmillan, 1899-1930), vol. IV, pp.520-21.

${ }^{3}$ Robert Sutcliffe, British Expeditionary Warfare and the Defeat of Napoleon, 1793-1815 (Woodbridge: Boydell Press, 2016); Roger Knight, Britain Against Napoleon: The Organisation of Victory, 1793-1815 (London: Penguin, 2014), p.143.
} 
Yet the project still affords some interesting insights into British strategic thinking regarding the Netherlands, and into the relatively slapdash methods of preparing military operations in the mid-1790s. This article will outline the key features of the proposed expedition, showing that it was conceived through perceived strategic necessity and that it was predicated on a presumed lack of Dutch opposition. The article will also outline the military difficulties faced and will show that these were exacerbated by the lack of detailed planning. In this the 1796 project anticipated in microcosm many of the tropes of future expeditions, including the much larger Anglo-Russian descent on the Netherlands in 1799.

The decision to launch a spoiling attack on the Dutch fleet was driven primarily by strategic concern for a potential threat to Britain's southeast coast and London. The Royal Navy's defensive strategy of covering the Western Approaches pre-supposed that the enemy's main forces would come from the direction of the Bay of Biscay or the Atlantic - the direction of Spain and France. The prospect of a large and well-manned hostile fleet in the North Sea, therefore, caused a great deal of consternation, and would indeed prove a key inspiration behind British raids or expeditions in 1798, 1799, 1805, 1809, and 1813-14. ${ }^{4}$ While there was no intimation of an immediate threat from that quarter in 1796, the conquest of the Netherlands had left the sizeable Dutch battlefleet at France's disposal, and British intelligence sources in the early months of the year indicated that a good part of this fleet was being fitted out for active operations..$^{5}$ The destruction of this force was considered desirable in order to neutralize any potential threat. Although at this stage Britain possessed neither the available military strength nor the political will to change a major campaign, an attack by a naval squadron seconded by land forces was deemed feasible. A memorandum of 1 October even enthusiastically suggested that the expedition might establish a permanent presence on Texel Island, which would blockade the Texel as effectively as a naval squadron, and at half the cost. ${ }^{6}$ The orders for Colonel John Doyle, the commander of the land force of the 1796 expedition, included vague instructions for the maintenance of troops on the island, but the prospect of creating a 'Dutch Gibraltar' does not appear to have featured seriously in the planning. ${ }^{7}$ It was, however, consistent with similar suggestions concerning potential British seizures of Dutch coastal islands

\footnotetext{
${ }^{4}$ N.A.M. Rodger, 'Seapower and Empire; Cause and Effect' in Bob Moore \& Henk van Nierop (ed.), Colonial Empires Compared, Britain and the Netherlands 1750-1850 (Aldershot: Ashgate, 2003), p.110; Christopher Hall, British Strategy in the Napoleonic War, 1803-1815 (Manchester: Manchester University Press, 1992), p.81; Roger Knight and Martin Wilcox, Sustaining the Fleet, 1793-1815: War, the British Navy, and the Contractor State (Woodbridge: Boydell Press, 2010), p.192.

${ }^{5}$ H.T. Colenbrander (ed.), Gedenkstukken der Algemeene Geschiedenis van Nederland van 1795 tot 1840 (10 vols, 'S-Gravenhage: Martinus Nijhoff, 1905-22), vol. II, p.362, Barclay to Grenville, 26 April 1796.

${ }^{6}$ The National Archives, London (TNA), WO 1/178, Memorandum 1 October 1796.

${ }^{7}$ TNA, WO 1/178, Dundas to Doyle, 10 October 1796.
}

Corresponding Author: Graeme Callister, graemecallister@gmail.com Citation: Callister, G. (2021). Britain's Not-so-Grand Strategy: The Projected Expedition Against the Texel, 1796. Academia Letters, Article 3049. https : //doi .org/10.20935/AL3049. 
that resurfaced periodically throughout the war. ${ }^{8}$

In addition to a perceived strategic necessity, there was also a distinct feeling in British military and political circles that any expedition might meet little resistance. British opinion had, by 1796, persuaded itself that the Dutch were less than enthusiastic about their new French alliance and that they were as likely to support as to oppose British military action. ${ }^{9}$ A War Office memorandum in September 1796 averred that the weak Dutch garrison troops - projected at no more than 2,000 men - 'are so averse to the present government that they would not make much opposition', and that 'of the peasantry, seafaring and laboring people in general, I am of the opinion it is only necessary to offer them a little assistance to rid themselves of their tyrants'. ${ }^{10}$ This, it was thought, would negate some of the danger to British forces, and indeed there seems to have been an implicit hope that the expedition might have provoked a wider crisis in Franco-Dutch relations. ${ }^{11}$ In this, the project certainly prefigured the Grand Expedition of 1799, which was predicated on the notion of widespread Dutch support for a British invasion. ${ }^{12}$ Any planned descent on the Netherlands was made more feasible, it was felt, by the supposedly favorable disposition of the target population.

Due to its perceived strategic importance, the planners took pains to keep the proposed expedition secret. Those who knew about the preparations had little inkling of the destination, with newspaper speculation naming Flushing as a target, and the official word being spread that the troops were intended for the defense of Portugal. ${ }^{13}$ Some soldiers believed that they were embarking for Gibraltar. ${ }^{14}$ In maintaining a degree of secrecy the expedition was doubtless aided by its relatively small scale; the 1,500 soldiers were embarked on only four troopships and attracted little attention, unlike the major invasion of the Netherlands three years later, which employed almost three hundred transport vessels. ${ }^{15}$ Nevertheless, there were indications that the Dutch became aware of the threat; a naval reconnaissance in late October found no signs of Dutch shipping, which was interpreted as a sign that they had gotten wind

\footnotetext{
${ }^{8}$ British Library, London (BL), Add MSS 38243, correspondence between Liverpool and Lt Gen. Don, 24 \& 27 October 1809; George Spencer (ed. Julian Corbett \& H. W. Richmond), Private Papers of George, Second Earl Spencer, First Lord of the Admiralty 1794-1801 (4 vols, London: Navy Records Society, 1913-1924), vol. 4, p.286.

${ }^{9}$ Graeme Callister, War, Public Opinion and Policy in Britain, France and the Netherlands, 1785-1815 (Cham: Palgrave Macmillan, 2017), pp.232-34

${ }^{10}$ TNA, WO $1 / 178$, 'Remarks and suggestions on the probability of capturing the Dutch fleet by attacking it at anchor in the Texel', 24 September 1796.

${ }^{11}$ Spencer, Private Papers, vol. 1, pp.302-303, Buckingham to Spencer, 28 September 1796.

${ }^{12}$ Callister, War, Public Opinion and Policy, pp.267-68.

${ }^{13}$ Star and Evening Advertiser, 11 November 1796; Fortescue, History of the British Army, vol. IV, p.521.

${ }^{14}$ London Chronicle, 10 November 1796; The Times, 12 November 1796.

${ }^{15}$ Camperdown, Admiral Duncan, p.79; Knight, Britain Against Napoleon, pp.192-93.
}

Corresponding Author: Graeme Callister, graemecallister@gmail.com Citation: Callister, G. (2021). Britain's Not-so-Grand Strategy: The Projected Expedition Against the Texel, 1796. Academia Letters, Article 3049. https://doi .org/10.20935/AL3049. 
of the impending attack. ${ }^{16}$

The need to attack Dutch shipping at anchor meant that the 1796 expedition was planned as an amphibious operation, calling for close cooperation between naval and land forces. Duncan's North Sea Fleet would provide the bulk of the fighting force, while the land troops would consist of the 10th and 87th Regiments under Doyle. The operational plan was risky. It was intended that Duncan's ships would sail into the Texel to grapple with the Dutch vessels, while the small force of infantry, supported by Duncan's marines, would land to capture the enemy shore batteries to ensure the navy's safe passage. ${ }^{17}$ The troops and commanders involved had a little track record of amphibious operations; indeed, the British in general could at this stage boast few successfully combined maneuvers, and such expeditions were often riven by interservice rivalry. ${ }^{18}$ The largest risk came perhaps for the land forces. Doyle's orders were vague, commanding him only to assault and take the enemy positions on Texel Island and Den Helder, without showing any particular appreciation of the situation he might face. In the absence of firm intelligence, it was by no means guaranteed that the soldiers would be able to capture their objectives, notwithstanding the potential disaffection of the Dutch garrison, and even if they did so there was no certainty of a safe withdrawal. ${ }^{19}$ Despite Duncan's orders to take every care to secure the retreat of the troops, enemy action or the ever-present risk of bad weather might easily prevent re-embarkation, as it would to disastrous effect at Ostend in May 1798 , necessitating the surrender of almost the entire expeditionary force. ${ }^{20}$ To add to the difficulties, the expedition was not ordered to proceed until 12 October, when conditions in the North Sea were far from favorable for amphibious action. Even if the passage of Den Helder was secured against hostile land batteries, the difficulties facing the fleet in carrying out its seaborne assault in the relatively shallow anchorage remained significant. However, the prospect of neutralizing the enemy navy and easing the burden of blockade proved tempting enough for London to order the endeavor. ${ }^{21}$

In the event, however, no attack took place. Poor weather off the Dutch coast left Duncan unwilling to risk his ships, while Doyle agreed that a successful landing in such conditions would be impossible. After cruising off the Texel for a fortnight waiting in vain for a change in

\footnotetext{
${ }^{16}$ TNA, WO 1/178, Doyle to Henry Dundas, 30 October 1796.

${ }^{17}$ TNA, WO 1/178, Doyle to Henry Dundas, 30 October 1796.

${ }^{18}$ Sutcliffe, British Expeditionary Warfare, pp.124-25. Public Characters of 1806 (London: Richard Phillips, 1806), p.64 claimed that 'perfect cordiality' subsisted between Doyle and Duncan, although of course the relationship was never tested under fire.

${ }^{19}$ TNA, WO 1/178, Dundas to Doyle, 10 October 1796.

${ }^{20}$ Camperdown, Admiral Duncan, p.80;Sutcliffe, British Expeditionary Warfare, p.127; Hall, British Strategy, p.83.

${ }^{21}$ TNA, WO 1/178, Dundas to Doyle, 10 October 1796.
}

Corresponding Author: Graeme Callister, graemecallister@gmail.com Citation: Callister, G. (2021). Britain's Not-so-Grand Strategy: The Projected Expedition Against the Texel, 1796. Academia Letters, Article 3049. https://doi .org/10.20935/AL3049. 
the weather, Duncan dispatched the troopships for home. He remained on station for another three weeks before deteriorating conditions drove him back to port, having achieved nothing other than the capture of a rich prize returning from Batavia. ${ }^{22}$ By this stage the immediate strategic imperative for a pre-emptive strike had in any case diminished; new intelligence reports highlighted the continued lack of preparedness of the Dutch fleet, while the turning weather was thought to render the likelihood of a Dutch sortie remote. ${ }^{23}$

The 1796 expedition, as uneventful as it proved, remains of interest. It highlights the continued strategic concern over the sensitive North Sea littoral, and the continued belief that the Dutch remained, at heart, friends of Great Britain. The vague orders, lack of upto-date intelligence, and the wholly inappropriate season of the year also point to the rather clumsy nature of military preparations. In this the 1796 expedition highlights issues that would influence and dog British expeditions in the Low Countries for the next decade and more.

\footnotetext{
${ }^{22}$ Oracle, 12 November 1796

${ }^{23}$ Colenbrander (ed.), Gedenkstukken, vol. II, p.367, Barclay to Canning, 9 November 1796; Morning Chronicle, 7 November 1796.
} 